\author{
Andrzej Indrzejczak \\ Katedra Logiki i Metodologii Nauk \\ Uniwersytet Łódzki \\ indrzej@filozof.uni.lodz.pl \\ Beata Promińska \\ Katedra Logiki i Metodologii Nauk \\ Uniwersytet Łódzki \\ beaprom@uni.lodz.pl
}

\title{
UWAGI O FORMACH KONTRARGUMENTACJI
}

\begin{abstract}
ABSTRAKT
Prezentowany tekst stanowi elementarne wprowadzenie do problematyki kontrargumentacji. Sposoby reakcji na nieakceptowane stanowisko w dyskusji uporządkowano według czterech możliwych przedmiotów ataku: nadawca, charakter i siła argumentu, przesłanki, teza. Omówione zostały najważniejsze strategie ataku oraz oceniono ich logiczną wartość
\end{abstract}

\section{SŁOWA KLUCZOWE}

Argumenty, kontrargumenty, dyskusja, fortele erystyczne.

\section{WSTĘP}

Jedną z najważniejszych form przekonywania, przynajmniej z logicznego punktu widzenia, jest argumentacja. Tradycyjnie termin ten stosowany jest do tych form perswazji, które odnoszą się do sfery ludzkiego rozumu, w przeciwieństwie do agitacji oddziałującej na emocję, czy propagandy, która wpływa na wolę odbiorców. Sprawy te zresztą łatwiej rozdzielać w teorii niż w praktyce, a skuteczna perswazja zazwyczaj i tak działa kompleksowo. Toteż w dalszych rozważaniach nie będziemy sztywno rozdzielać tych aspektów perswazji, które mają charakter bardziej racjonalny od tych, które można uznać wręcz za irracjonalne (choć często skuteczne). Spoglądamy jednak na analizowane problemy z punktu widzenia logiki, zatem pozwolimy sobie na uwagi ocenia- 
jące stopień rzetelności logicznej (a czasem też etycznej) stosowanych praktyk.

Dowolna argumentacja rozważana w całości zawiera zazwyczaj różne składniki; poniżej skupimy się na roli rozumowań w kontekście argumentacji. Rozumowania użyte $w$ ramach argumentacji (wypowiedzi argumentacyjnej) w celu przekonania kogoś do uznania (lub odrzucenia) pewnych przekonań będziemy określali krótko jako argumenty. Czasami argumentami określa się same przesłanki takiego rozumowania; wniosek zazwyczaj nazywa się tezą danego argumentu. Argumentów używa się również w celu odrzucenia jakiegoś poglądu i wtedy mówić możemy o kontrargumentacji.

W pewnym uproszczeniu można powiedzieć, że w ramach teorii argumentacji interesuje nas, w jaki sposób argumenty konstruować, oraz jak na argumenty reagować (kontrargumentacja). Oba zagadnienia są ze sobą ściśle powiązane i zawierają cały szereg kwestii bardziej szczegółowych. Mówiąc o konstrukcji argumentu mamy na myśli zarówno proces jego tworzenia (przygotowywania) jak i strukturę gotowego rozumowania. Biorąc pod uwagę, że argumenty nie istnieją w próżni musimy zresztą już podczas ich tworzenia uwzględnić fakt odbioru. Należy wiedzieć, w jaki sposób je analizować i oceniać, oraz w jaki sposób poddawać je krytyce. Uwzględnienie możliwej reakcji już na poziomie konstruowania argumentu sprzyja podniesieniu jego skuteczności.

Wydaje się jednak, że pomimo bogatej literatury dotyczącej argumentacji i perswazji w ogóle, metodologiczna analiza form jakie może przybrać kontrargumentacja nie jest zbyt rozwinięta. Tradycyjnie, za Schopenhauerem, zwykło się wyróżniać sposoby (modi) (modus ad rem i modus ad hominem) oraz drogi ataku tez dyskutanta. W tym drugim przypadku wyróżnia się drogę bezpośrednią (negacja przesłanek lub związku między przesłankami a wnioskiem) i pośrednią (apagogiczna lub przez kontrprzykład). Nieco dalej zaproponujemy pewien sposób podziału form kontrargumentacji, który - choć zbliżony do tradycyjnego - ma jednak bardziej jednorodny charakter. Spróbujemy też dokonać oceny wartości różnych form ataku. Formy kontrargumentacji będziemy rozważać z dwóch punktów widzenia - atakującego (oponenta) i atakowanego (proponenta) (ze względu na możliwe i preferowane reakcje).

Argument jest skuteczny jeżeli jego konkluzja (teza) zostaje zaakceptowana przez odbiorców. Stopień akceptacji może być różny; od bezwzględnego uznania wniosku za prawdziwy (lub fałszywy w przypadku argumentacji odrzucającej) po życzliwą skłonność do uznania możliwości wniosku. Skuteczność argumentu jest niezależna od jego logicznej poprawności i zazwyczaj akceptacja argumentu nie jest wynikiem jego obiektywnej wartości. Odbiorca często nie analizuje argumentów, gdyż po prostu wierzy nadawcy - ma do 
niego zaufanie lub chciałby, żeby stan rzeczy opisany we wniosku faktycznie miał miejsce. $Z$ taką ,życzeniową" reakcją mamy często do czynienia zwłaszcza w przypadku odbiorców mało krytycznych i łatwo ulegających perswazji. Dobrego przykładu dostarcza tutaj fenomen popularności polityków o nastawieniu demagogicznym, którzy w niezbyt wyrafinowany sposób po prostu obiecują swoim zwolennikom spełnienie wszystkich oczekiwań, bez względu na obiektywne uwarunkowania. Należy również zauważyć, że w przypadku odbiorcy słabo przygotowanego do analizy argumentacji może nastąpić odrzucenie niewygodnej konkluzji bez jakiejkolwiek próby rozważenia przedłożonego argumentu.

Z punktu widzenia celów tego artykułu bardziej interesująca jest analiza reakcji krytycznych, będących wynikiem rozpatrzenia argumentu. Odbiorca krytyczny powinien dokonać oceny wniosku, przesłanek i całego argumentu, tzn. stopnia uzasadnienia wniosku przez przesłanki. Zależnie od dokonanej oceny można dokonać ataku na każdy $\mathrm{z}$ wyodrębnionych składników. Ze względu na powszechność tej praktyki dołączymy też do wyodrębnionych celów ataku nadawcę komunikatu, choć tutaj można mieć najwięcej obiekcji natury logicznej (oraz etycznej) odnośnie do wartości takiego postępowania. Od analizy ataku na nadawcę zaczniemy nasze rozważania.

\section{NADAWCA}

Atakowanie osoby dyskutanta jest niezwykle rozpowszechnionym sposobem walki słownej i może przybierać rozmaite formy. Ogólnie rzecz biorąc mamy tu do czynienia $\mathrm{z}$ argumentami odnoszącymi się do osoby. Wspomniana technika występuje $\mathrm{w}$ dwóch odmianach określanych mianem argumentum ad personam i argumentum ad hominem. Wielu autorów używa tych terminów synonimicznie, jednak wydaje się, że warto je rozróżniać. $\mathrm{Z}$ argumentum ad hominem mamy do czynienia wtedy, gdy w dyskusji odwołujemy się do poglądów oponenta aby wykorzystać je dla własnych celów. Argumenty tego typu omówimy zatem w paragrafie poświęconym atakowi na przesłanki; tutaj odnotujmy jedynie, że można je uznać za technikę nie tylko skuteczną, ale i (zazwyczaj) uczciwą, czego nie da się raczej powiedzieć o stosowaniu argumentum ad personam. Są to argumenty, w których poglądy oponenta podważa się w sposób pośredni, wskazując, że jest to osoba nieuczciwa, niemoralna, niekompetentna itp. Stosując je zmierza się do skompromitowania danej osoby i w konsekwencji do utraty jej wiarygodności. Przecież, skoro $X$ jest głupi i zły, to na pewno kłamie.

W skrajnych wypadkach mamy do czynienia z publicznym obrażaniem dyskutanta, a jeżeli on również odpowie w ten sposób dyskusja łatwo może się 
zamienić w kłótnię. Stanowczo odradzamy taki sposób „dyskutowania”, gdyż siła głosu bynajmniej nie wzmacnia siły argumentacji. Zgodnie ze starożytną maksymą spór powinno się prowadzić delikatnie co do formy, a mocno co do treści, a nie zaś na odwrót.

W szczególny sposób argumentum ad personam jest reprezentowane w zabiegu zwanym tu quoque (ty także). Przykładowo, palącemu lekarzowi, który zaleca nam porzucenie palenia, zarzucamy, że sam tego nie zrobił, osobie duchownej, że źle się prowadzi itp. W argumentacji tego typu zwracamy uwagę na sprzeczność lub - co najmniej - na znaczący dystans występujący między zachowaniem a głoszonymi poglądami, co sugeruje, że albo zachowanie to nie jest takie złe, albo osoba krytykująca nie ma moralnego prawa tego czynić. Wydaje się, że argumenty tego typu są zasadne, jednak w wielu wypadkach należałoby poczynić rozróżnienie pomiędzy głoszonym przekonaniem a niezgodnym $\mathrm{z}$ nim zachowaniem. Ludzie często wyznają i propagują bardzo wymagające systemy zasad, którym trudno sprostać, w tej sytuacji kwestionowanie wagi takich zaleceń na podstawie zachowania propagatora nie wydaje się słuszne. Dowcipnie podsumował to pewien etyk, który w odpowiedzi na zarzut, że „źle się prowadzi” stwierdził: „A czy ktoś widział, żeby drogowskaz szedł drogą, którą wskazuje?"

$\mathrm{Z}$ punktu widzenia logiki argument ad personam w swoich rozmaitych formach podpada pod pojęcie błędu rozumowania zwanego ignoratio elenchi (nieznajomość dowodzonej tezy). Błąd taki popełniamy kiedy wykazujemy coś innego niż było pierwotnie zamierzone. Argumentując przeciwko dyskutantowi istotnie nie wykazujemy, że jego twierdzenia są fałszywe a jedynie, że posiada on określone wady.

Świadomość tego mechanizmu pozwala nam podjąć obronę w sytuacji, gdy sami stajemy się przedmiotem takiego ataku. Należy zdać sobie sprawę, że argumenty ad personam są wykorzystywane często jako skuteczny sposób odwrócenia uwagi od właściwego przedmiotu sporu, wtedy gdy atakujący zdaje sobie sprawę, że stoi na straconej pozycji. Tym samym zalicza się on do arsenału innych znanych zabiegów erystycznych służących wytrącaniu rozmówcy $\mathrm{z}$ równowagi. Niestety ataki takie często są skuteczne, w tym sensie, że osoba atakowana ulega emocjom, zaczyna reagować histerycznie i często odpłaca ze swej strony atakami podobnego rodzaju. Jest tak zwłaszcza wtedy gdy postawione zarzuty są nieprawdziwe i trudno zapanować nad oburzeniem z powodu bezczelności oponenta. Niestety jest to bardzo zły sposób reakcji gdyż godzimy się w ten sposób na warunki atakującego a w naszym interesie jest raczej za wszelką cenę powrócić do kwestii merytorycznych - nawet za cenę przyznania racji dyskutantowi - zamiast 
przekonywać wszystkich, że jesteśmy ofiarą pomówień. Odpieranie wprost zarzutów zawartych w argumentacji czasami przynosi wręcz odwrotne efekty („winny się thumaczy!”), czasem lepiej powiedzieć: „W porządku, wszyscy już wiedzą, że jestem leniem, łajdakiem i kretynem, ale może spróbujemy ponownie rozważyć problem, od którego zaczął się nasz spór!”. Bardzo dobrym sposobem odparcia ataków personalnych jest stosowanie odpowiedzi ironicznych, np. wylewne podziękowanie dyskutantowi, że raczył wszystkich obecnych poinformować o tak interesujących faktach z naszego życia (nawet nam nie znanych!). Zwłaszcza w dyskusjach publicznych taka reakcja nie tylko wytrąca oręż z ręki naszego rozmówcy ale zyskuje nam przychylność i zaufanie audytorium (skoro tak reaguje, to znaczy, że to plotki). Na koniec coś dla bardziej wyrafinowanych logicznie słuchaczy dyskusji; na zarzut typu „Ty zawsze kłamiesz” można odpowiedzieć „Ty jesteś osobą prawdomówną, uczciwą, (...)".

Czy zatem atakowanie osoby jest całkowicie nieuczciwym i nierzetelnym sposobem kontrargumentowania? Niekoniecznie. Bywają sytuacje kiedy przytoczenie faktów z czyjegoś życia może pokazać, że osoba ta ma osobisty interes w przekonaniu nas do pewnej decyzji choć w argumentacji wskazuje na obiektywne wartości. Np. rozważmy sytuację przetargu gdy w firmie dyskutuje się komu powierzyć wykonanie odpowiedzialnego zadanie. Jeden z rozmówców przedstawia bardzo konkretne informacje, które mają przekonać pozostałych, że najlepszym kandydatem jest firma X. Nie wspomina jedynie o tym, że jego syn pełni w tej firmie odpowiedzialną funkcję, a on sam ma pakiet udziałów. Ujawnienie tej informacji jest z pewnością przypadkiem zastosowania argumentum ad personam, ale czy istotnie nielogicznym i nieuczciwym? Nawet jeżeli firma $X$ jest obiektywnie rzecz biorąc naprawdę najlepszym kandydatem do wykonania zlecenia, to w grę wchodzi tu jednak kwestia interesu własnego. Dlatego wydaje się, że w uzasadnionych przypadkach argumenty ad personam są rzetelnym sposobem kontrargumentacji. Problem polega każdorazowo na rozstrzygnięciu czy ujawniane fakty z czyjegoś życia lub cechy charakteru są relewantne do rozważanej sprawy.

Podsumowując: oceniając wartość konkretnego argumentu ad personam warto zacząć od rozstrzygnięcia czy postawiony zarzut jest prawdziwy. Nawet jeśli jest prawdziwy, to należy zastanowić się czy postawiony zarzut ma związek $\mathrm{z}$ argumentem atakowanego. Dopiero gdy w obu przypadkach odpowiedź wypada twierdząco można uznać, że jest to atak zasadny. 


\section{WARTOŚĆ ARGUMENTU}

Atak może dotyczyć związku przesłanek z wnioskiem, czyli stopnia uzasadnienia wniosku przez przesłanki. Oczywiście najlepiej jest jeżeli argument ma charakter dedukcyjny, tzn. gdy wniosek wynika z przesłanek. Przypomnijmy, że relacja wynikania wyklucza sytuację, gdy przesłanki są prawdziwe, a wniosek mimo to fałszywy. Relacja ta ma charakter formalny, tzn. jej zachodzenie nie zależy od faktów, ale od znaczenia słów i struktury zdań. W szczególności pamiętajmy, że $\mathrm{z}$ fałszywych przesłanek mogą wynikać zarówno prawdziwe jak i fałszywe wnioski.

Atak dokonany na związek wniosku z przesłankami zazwyczaj przybiera postać kontrprzykładu. Mamy tu na myśli replikę polegającą na zaprezentowaniu argumentu o takiej samej formie, ale ewidentnie fałszywym wniosku przy ewidentnie prawdziwych przesłankach. Należy pamiętać, że przy takiej formie krytyki trzeba uwzględnić intencje argumentującego. Jeżeli autor argumentacji twierdzi, że wniosek wynika z przesłanek chociaż faktycznie rozumowanie nie jest dedukcyjne, to popełnia błąd formalny. Dostarczenie kontrprzykładu $\mathrm{w}$ takiej sytuacji definitywnie pokazuje brak uzasadnienia wniosku, nawet jeżeli nie sposób odrzucić przesłanek. Inaczej jest w przypad$\mathrm{ku}$, gdy argument nie jest prezentowany jako niezawodny ale jako uprawdopodabniający. W takiej sytuacji trudniej wykazać, że przesłanki nie uzasadniają wniosku. Podanie kontrprzykładu niczego nie załatwia skoro nasz dyskutant nie upiera się, że zawsze ilekroć przesłanki są prawdziwe, to wniosek też. Zazwyczaj sposób podważania wartości takiego argumentu w mniejszym stopniu odwołuje się do jego formy a bardziej do kwestii merytorycznych.

Trzeba przyznać, że ta forma kontrargumentacji, choć logicznie zasadna, ma liczne wady. Po pierwsze, nawet osoba, która posiada wykształcenie logiczne zazwyczaj nie jest w stanie szybko zauważyć, że argument dyskutanta jest logicznie wadliwy, a nawet jeżeli to zauważy, to niekoniecznie jest w stanie natychmiast znaleźć przekonujący kontrprzykład. Zazwyczaj wykazanie braku wynikania, lub słabego stopnia uzasadnienia (w przypadku niededukcyjnych argumentów) wymaga analizy na spokojnie i z wykorzystaniem logicznej aparatury. Toteż taka forma ataku ogranicza się zazwyczaj do bardzo prostych rozumowań w dyskusjach. Inaczej jest w pisemnych polemikach, gdzie mamy czas i możliwość przeanalizowania cudzych argumentów.

Typowe proste przypadki niepoprawnych rozumowań, które łatwo zidentyfikować i skontrować za pomocą kontrprzykładu to argumenty oparte na wnioskowaniu z następnika prawdziwej implikacji o jej poprzedniku lub negacji poprzednika o negacji następnika, mylenie konwersji implikacji z jej kontrapozycją itp. 
Dodatkowo trzeba podkreślić, że na skuteczności takiej formy kontrargumentacji niekorzystnie się odbija zazwyczaj niska kultura logiczna dyskutujących i audytorium. W tej sytuacji nawet trafnie dobrany kontrprzykład może być zignorowany lub uznany za „fanaberie”.

Ponadto, oceniając poprawność czyjegoś rozumowania musimy pamiętać, że zazwyczaj mamy do czynienia z rozumowaniami entymematycznymi, czyli niepełnymi. Przykładowo, skłonni jesteśmy uznać, że ktoś, kto mówi w mroźny zimowy dzień: „Pada deszcz. Będzie ślisko” - wygłasza poprawne rozumowanie, chociaż jego schemat w logice zdań wygląda $p / q$. Autor tego rozumowania pomija jednak przesłanki, które dla niego i dla dowolnego odbiorcy wydają się oczywiste. Po ich dodaniu otrzymamy rozwinięte rozumowanie: ,Jeżeli pada deszcz, to jest mokro. Pada deszcz. Jest niska temperatura. Jeżeli jest mokro i jest niska temperatura, to będzie ślisko. Zatem, będzie ślisko", które podpada pod schemat poprawnego rozumowania:

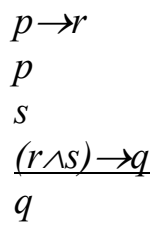

Rozumowania entymematyczne są $\mathrm{w}$ praktyce argumentacji pewnym standardem i jako takie nie są ani poprawne, ani niepoprawne, gdyż trudno bez stosownych uzupełnień dokonać oceny ich logicznej wartości. Jednak z entymematami związane jest duże ryzyko błędu, zarówno od strony ich konstrukcji, jak i rekonstrukcji. Prezentując rozumowania nie możemy pominąć za dużo, gdyż argument zawierający zbyt dużo luk może się okazać w praktyce niemożliwy do zrekonstruowania. Powinniśmy w tym punkcie kierować się leibnizjańską zasadą racji dostatecznej, tzn. zadbać by wyrażone explicite uzasadnienie było wystarczające dla odbiorcy naszego argumentu.

Szczególnie poważnym błędem jest umyślne pominięcie tych przesłanek, o których wiemy, że są fałszywe lub co najmniej niewiarygodne. Popełniamy wówczas nie tylko błąd materialny; dodatkowo próbujemy jego wystąpienie zataić, a zatem działamy w złej wierze.

W przypadku ataku na nasz argument należy pamiętać o ujawnieniu brakujących przesłanek, których pominięcie jest ewidentne. Dopiero po takim uzupełnieniu można dokonać ich oceny. Problem sprowadza się do kwestii, co możemy w danym wypadku uznać za „oczywiste” pominięcie.

Rekonstruując czyjeś rozumowanie powinniśmy stosować zasadę życzliwej interpretacji, nie można jednak przekroczyć pewnych granic. Pamiętajmy 
bowiem, że każde niepoprawne rozumowanie można na siłę poprawić dodając do niego nowe przesłanki. Dwa skrajne przypadki takiego postępowania wymagają dodania zaledwie jednej.

Jeżeli dodamy dowolne zdanie sprzeczne z którąkolwiek z przesłanek już występujących, to oczywiście otrzymamy rozumowanie trywialnie poprawne na mocy zasady Dunsa Szkota, która gwarantuje, że ze sprzecznych przesłanek wynika logicznie dowolne zdanie.

Jeżeli dodamy do przesłanek zdanie, które jest wnioskiem tego rozumowania, to też mamy gwarancję formalnej poprawności, a także - zupełnej zbędności pozostałych przesłanek. Jest tak dlatego, że każde zdanie wynika z niego samego - relacja wynikania jest bowiem zwrotna. Bardziej wyrafinowaną odmianą tego zabiegu będzie wprowadzenie przesłanki równoważnej z wnioskiem, ale której struktura nie pozwala tego natychmiast zauważyć. Tak czy inaczej, mamy wtedy do czynienia z błędnym kołem w rozumowaniu (tradycyjna nazwa circulus in probando) w wersji bezpośredniej.

Wykroczenie takie może wystąpić również w formie pośredniej. Mamy wtedy do czynienia z co najmniej dwoma rozumowaniami składającymi się na rozbudowaną argumentację, w której wniosek rozumowania $\mathrm{R}$ (lub jego równoważnik) jest użyty w rozumowaniu $R^{\prime}$ jako przesłanka uzasadniająca dla jednej z przesłanek rozumowania $R$. Oto prosty przykład:

Bóg istnieje, gdyż tak mówi Pismo Święte. A Pismo Święte nie kłamie, gdyż jego tekst został podyktowany przez Boga [por. Trzęsicki 2000].

Generalnie, uzupełnianie jakiegoś rozumowania dowolnymi zdaniami, które zapewnią jego formalną poprawność podpada pod ogólniejszy błąd petitio principi (żądanie zasady), czyli wnioskowania z nieuzasadnionych przesłanek, ale tym błędem zajmiemy się w kolejnym paragrafie.

$\mathrm{Na}$ koniec należy podkreślić, że wykazanie braku wynikania nie jest wykazaniem fałszywości wniosku. Broniona teza może być prawdziwa choć słabo uzasadniona. Więc nie należy się od razu poddawać. Typowym błędem popełnianym często przez niedoświadczonych lub nieśmiałych dyskutantów jest wycofanie się $\mathrm{w}$ takiej sytuacji $\mathrm{z}$ obrony tezy. Dobrze przygotowany dyskutant ma przygotowane inne argumenty na jej poparcie.

\section{PRZESŁANKI}

W przypadku podjęcia ataku na przesłanki możemy wykazywać, że są nieprawdziwe (błąd materialny) lub nieuzasadnione (petitio principi). Metoda wykazywania tych błędów może być bezpośrednia lub pośrednia (przez 
zbudowanie innego rozumowania, które prowadzi do nieakceptowanych przez proponenta konsekwencji).

Jeżeli oponent jest w stanie wykazać fałszywość co najmniej jednej przesłanki, to wykazuje tym samym, że w argumentacji popełniono błąd materialny. Sytuacja tego typu wskazuje, że dany argument nie dostarcza uzasadnienia proponowanego wniosku. Podobnie jest w przypadku, gdy wprawdzie atakujący nie wykazał fałszywości ani jednej przesłanki, ale jest w stanie poddać w wątpliwość ich prawdziwość i wykazać, że są nieuzasadnione (petitio principi).

Należy pamiętać, że o błędzie materialnym można mówić tylko w przypadku, gdy rozumowanie jest podawane jako argument lub dowód uzasadniający prawdziwość wniosku. Często przeprowadzamy przecież wnioskowania $\mathrm{w}$ oparciu o niepewne przesłanki. W takiej sytuacji mówienie o błędzie materialnym nie ma sensu. Poprawnie przeprowadzone wnioskowanie $\mathrm{z}$ takich przesłanek, które doprowadziło nas do fałszywego wniosku nie jest przecież jego uzasadnieniem. Stanowi raczej uzasadnienie dla odrzucenia zakładanych przesłanek.

Szczególnym przypadkiem błędu materialnego jest występowanie sprzeczności w przesłankach. Nie możemy przecież zaakceptować całego tekstu, w którym dostrzegamy sprzeczność, gdyż na pewno przynajmniej niektóre zdania w nim występujące są fałszywe, choć możemy nie wiedzieć które. Zauważmy, że wykrycie sprzeczności w przesłankach czyjejś argumentacji jest bardzo poważnym kontrargumentem. $Z$ reguły prowadzi ono do dalszych konsekwencji w postaci zarzutu braku elementarnych kompetencji logicznych u naszego dyskutanta. Jest to wprawdzie też forma argumentum ad personam ale akceptowalna. W zasadzie wykrycie błędu materialnego w ogóle (a nie tylko sprzeczności) może stanowić podstawę do podważenia czyjejś kompetencji, w tym wypadku w dziedzinie, której dotyczą przesłanki atakowanego argumentu.

Błąd petitio principi (a w szczególności błędne koło w dowodzeniu) nie jest błędem materialnym w sensie ścisłym. Przesłanki mogą być nieuzasadnione, ale jednak prawdziwe. Jednak nawet w przypadku rozumowania poprawnego, w którym wartość logiczna przesłanek jest wysoce niepewna, ten stopień niepewności obciąża również wniosek.

Osoba, której zarzucamy petitio principi jest zobowiązana do przedstawienia argumentów, które stanowią wystarczające uzasadnienie zakwestionowanych przesłanek. Oczywiście musi zwracać uwagę, aby dostarczając kolejnych rozumowań nie popadła w błędne koło pośrednie lub inne omawiane przez nas wyżej błędy. Proces uzasadniania zakwestionowanych przesłanek 
można uznać za zakończony, jeżeli użyte w dodatkowych argumentach inne przesłanki nie budzą już wątpliwości oponenta.

Jak wspomnieliśmy wyżej atak na przesłanki może mieć charakter bezpośredni lub pośredni. W pierwszym wypadku okazujemy, że atakowana przesłanka jest fałszywa (lub nieprawdopodobna) gdy dysponujemy jakimś świadectwem jej fałszywości. Najłatwiej to uczynić gdy podważana przesłanka jest zdaniem jednostkowym, stwierdzającym jakiś fakt, lub zdaniem ogólnym. W tym drugim przypadku starczy znaleźć chociaż jeden przykład negatywny.

Pośrednia forma obalenia przesłanek polega na wyprowadzeniu z nich takiego wniosku, który będzie nie do zaakceptowania przez naszego dyskutanta (proponenta). Określenie „nie do zaakceptowania” jest dość pojemne. Mogą to być dowolne zdania fałszywe, ale takie, których fałszywość nie podlega dyskusji (przynajmniej w gronie dyskutujących). W grę wchodzą również takie twierdzenia, które są z jakiegoś powodu niewygodne dla proponenta, np. są niezgodne $z$ tym co deklarował wcześniej. W tym przypadku to naszemu dyskutantowi może $\mathrm{w}$ dalszym przebiegu dyskusji zależeć na wykazaniu ich fałszywości, ale wtedy powinien dążyć też do pokazania, że jego przesłanki wcale w sposób konieczny nie wiodły do takiej konsekwencji.

Zauważmy, że w takim przypadku mamy do czynienia z pewną formą argumentum ad hominem gdyż $\mathrm{w}$ dyskusji odwołujemy się do poglądów proponenta (wyrażonych w przesłankach argumentu) aby wykorzystać je dla własnych celów. Jest to zabieg bardzo skuteczny, gdyż proponentowi trudno zwalczać nasze wnioski jeżeli zostały wyprowadzone z przesłanek przez niego akceptowanych. Proponent rzetelny musi w takiej sytuacji wykazać, że rozumowanie przez nas przeprowadzone popełnia błąd formalny lub wycofać się z tych poglądów. Proponent mniej rzetelny ucieka się często w takich sytuacjach do innych zabiegów o charakterze erystycznym, np. stosuje „subtelne” rozróżnienia pojęciowe, chcąc wykazać, że co innego miał na myśli.

Omówiony wyżej zabieg można uznać za nieuczciwy, jeżeli korzystamy $\mathrm{w}$ argumentacji z poglądów proponenta, chociaż ich nie podzielamy. Popełniamy wtedy de facto świadomie błąd materialny w rozumowaniu. Generalnie można jednak uznać argumenty tego typu za technikę nie tylko skuteczną ale i uczciwą, czego nie da się w ogólności powiedzieć o stosowaniu argumentum ad personam. Inna sprawa, że przez udane zastosowanie argumentu ad hominem pośrednio budujemy też pewien atak ad personam. Mianowicie wykazując, że proponent oparł się na fałszywych przesłankach podważamy jego kompetencję w danej dziedzinie, a wykazując ich sprzeczność podważamy jego kompetencję logiczną. 
Za szczególny przypadek argumentum ad hominem można uznać niezwykle efektowny zabieg retoryczny zwany retorsio argumenti. Jest to wyprowadzenie $\mathrm{z}$ tych samych przesłanek, z których korzystał oponent, wniosku, który wyklucza się z jego wnioskiem. Dobrą ilustracją jest spór między sofistą Protagorasem a Euatlosem, jego uczniem. Protagoras miał dostać zapłatę za swoje nauki dopiero wtedy, gdy Euatlos wygra pierwszą sprawę w sądzie. Ponieważ przez dłuższy czas uczeń nie podejmował żadnych spraw więc Protagoras sam go pozwał i argumentował w sądzie następująco:

Mój uczeń tę sprawę wygra lub nie. W pierwszym wypadku musi mi zapłacić na mocy naszej umowy, gdyż będzie to jego pierwsza wygrana sprawa. W drugim też musi mi zapłacić, a to $\mathrm{z}$ wyroku sadu. Zatem w każdym wypadku musi mi zapłacić.

Jak widać, Protagoras użył w argumentacji formy dylematu konstrukcyjnego prostego. Uczeń zgodził się z pierwszą przesłanką ale argumentował, że odwrotnie - nie musi płacić w żadnym przypadku! Jeżeli sprawę wygra, to nic nie jest winien na mocy orzeczenia sądowego, a jeżeli przegra, to nic nie jest winien, zgodnie z umową. Pomińmy kwestię rozwiązania tego konkretnego dylematu. Ważna jest dla nas ogólna refleksja nad skutecznością takiej formy kontrargumentacji w warunkach dyskusji publicznej. Nie ma tu znaczenia, które z przedstawionych rozumowań jest logicznie poprawne (oba być nie mogą - chyba, że przesłanki są sprzeczne). Nawet jeśli rozumowanie proponenta było poprawne a oponenta nie, to $\mathrm{i}$ tak $\mathrm{u}$ audytorium zazwyczaj on uchodzi za zwycięzcę, przynajmniej w tej fazie dyskusji. Jest to być może jakiś bonus dla dyskutanta, który jest w stanie popisać się refleksem i nieoczekiwanie odwrócić na swoją korzyść wywody strony przeciwnej.

Zakończmy analogiczną uwagą jak w poprzednim podrozdziale. Trzeba pamiętać, że fałszywość przesłanek wcale nie przesądza o fałszywości wniosku - nawet w przypadku rozumowania dedukcyjnego - o czym wspominaliśmy wyżej.

\section{WNIOSEK}

W świetle powyższych uwag wydaje się, że najważniejszym, przynajmniej w sensie logicznym, sposobem ataku jest atak na wniosek. Przypomnijmy, atak na osobę uznaliśmy za nierzetelną formę kontrargumentacji, natomiast nawet udane ataki na przesłanki czy formę argumentu nie wykazują, że stanowisko przedstawione we wniosku jest fałszywe. Zatem chcąc wykazać 
fałszywość wniosku musimy go zaatakować, podobnie jak w przypadku ataku na przesłanki bezpośrednio lub pośrednio.

Z drugiej strony jeżeli nie chcemy uznać wniosku, to siłą rzeczy musimy się ustosunkować do pozostałych elementów argumentu. Musimy pamiętać, że odrzucenie wniosku niejako składa na nas obowiązek wykazania, że bądź przynajmniej jedna z przesłanek jest fałszywa, bądź, że rozumowanie nie jest dedukcyjne. Człowiek, który akceptuje przesłanki i zgadza się, że wynika z nich wniosek ale nie chce go zaakceptować zachowuje się irracjonalnie.

W dalszym ciągu skupimy się na pośredniej formie ataku na wniosek. Klasycznym przykładem zastosowania tej techniki są liczne dialogi Platona (424-344 r. p.n.e.), w których jako główna postać występuje jego mistrz Sokrates (469-399 r. p.n.e.). Sokrates chcąc wykazać komuś, że jego poglądy są błędne, przy pomocy pytań naprowadzał go na konsekwencje tychże poglądów. Na każdym kroku upewniał się też, że jego rozmówca zgadza się, że proponowane wnioski wynikają z przesłanek. W końcu pojawiały się takie wnioski, których rozmówca już nie mógł zaakceptować, gdyż albo były ewidentnie fałszywe, albo - co najmniej - nie do przyjęcia dla niego. Skoro jednak zgadzał się, że wynikają z wcześniejszych zdań, a zatem również z jego wyjściowych przesłanek, musiał uznać, że jego poglądy są błędne.

Taki sam mechanizm wykorzystywany jest także w nauce, w szczególności do sprawdzania hipotez. Chcąc wyjaśnić jakieś zjawisko, przyjmuje się wstępnie pewne hipotezy, czyli zdania ogólne, które thumaczą, jak do niego dochodzi, ale co do których prawdziwości nie mamy pewności. Z hipotez (łącznie z innymi uznanymi twierdzeniami) wyprowadzamy dedukcyjnie wnioski, których wartość logiczną możemy sprawdzić (np. przez obserwację lub eksperymenty). Jeżeli znajdziemy zdanie, które jest fałszywe, to znaczy, że któraś z naszych hipotez też jest fałszywa. W ten sposób dokonujemy falsyfikacji hipotezy.

Efektownym zabiegiem argumentacyjnym jest także stosowanie schematu rozumowania określanego mianem równi pochyłej, w którym, chcąc zakwestionować zdanie $\mathrm{p}$, pokazujemy, w jaki sposób ze zdania tego poprzez łańcuch implikacji wynika zdanie q, którego absolutnie zaakceptować nie można. Przyjęcie p jest zatem pierwszym krokiem, który wywołuje eskalację niepożądanych następstw, $\mathrm{z}$ czego prostym wnioskiem jest odrzucenie $\mathrm{p}$, jeżeli tych następstw chcemy uniknąć. Przykładowo, argumentując przeciwko zakazowi posiadania broni mówimy:

Oczywiście, taki zakaz jest konieczny. Ale czemu nie poszerzyć, go na wiatrówki, przecież z nich też można kogoś postrzelić, a nawet zabić! No, ale zabić można też przy pomocy noża, czy pałki, więc dlaczego zakazem nie objąć też narzędzi kuchennych! 
Rozumowania ukrywające się pod tego typu argumentacją są $\mathrm{w}$ istocie formalnie poprawnym wykorzystaniem reguł sylogizmu hipotetycznego i modus tollendo tollens. Zatem, jeżeli nie jesteśmy w stanie wskazać w nich błędu materialnego (zakwestionować co najmniej jednej implikacji w zbiorze przesłanek, wykazać brak związku między poprzednikiem a następnikiem), to musimy p odrzucić. Można też, broniąc się przed równią pochyłą, wydłużyć domniemany ciąg konsekwencji dalej, doprowadzając do groteskowych wniosków. Jeszcze inny sposób reakcji na równię pochyłą, to zaprezentowanie tzw. „różowego scenariusza” następstw, w odpowiedzi na przedstawiony przez oponenta czarny scenariusz.

Rozważmy na zakończenie jakie są warunki logicznej poprawności ataku pośredniego na wniosek (stosują się one zresztą również do ataku na przesłanki) - można je sprowadzić do następujących:

1. Wyprowadzony wniosek musi logicznie wynikać z tezy proponenta, inaczej jego fałszywość nie przesądza fałszywości tej tezy.

2. Teza proponenta jest jedyną przesłanką rozumowania oponenta lub - jeżeli użyto też innych przesłanek - to są one bez wątpienia prawdziwe (uwaga na entymematy!)

3. Teza proponenta nie jest przez oponenta zniekształcona (uogólnianie, zmiana sensu terminów - ogólnie ignoratio elenchi).

4. Wniosek wyprowadzony przez oponenta jest fałszywy (a nie tylko niewygodny dla proponenta).

Jeżeli warunki te są spełnione, to możemy uznać rzeczoną formę kontrargumentacji za w pełni logicznie poprawną.

\section{LITERATURA}

Czeżowski, T. (1958), O dyskusji i dyskutowaniu, [w:] Odczyty filozoficzne. Prace Wydziału Filologiczno-Filozoficznego - Towarzystwo Naukowe w Toruniu, s. 280-288,

Kochan, M. (2005), Pojedynek na stowa. Wydawnictwo ZNAK.

Marciszewski, M. (1994), Sztuka dyskutowania. Warszawa, Wydawnictwo Aleph.

Schopenhauer, A. Erystyka [wydanie dowolne],

Tokarz, M. (2006), Argumentacja, perswazja, manipulacja. Gdańskie Wydawnictwo Psychologiczne.

Trzęsicki, K. (2000), Logika. Nauka i sztuka. Białystok, Wydawnictwo Wyższej Szkoły Finansów i Zarządzania. 


\section{REMARKS ON THE FORM OF COUNTERARGUMENTATION \\ (Abstract)}

The paper provides an elementary introduction to the problems of counterarguments. The ways of possible critical reaction are divided according to four objects of attack: the proponent, strength of argument, premises, conclusion. The most important strategies of attack are discussed and evaluated according to their logical strength.

\section{KEYWORDS}

Arguments, counterarguments, discussion, eristic attacks 